\title{
Leadership Style In Improving Performance Through Engagement
}

\author{
Yupono Bagyo \\ STIE Malangkucecwara, Malang
}

\begin{abstract}
The key drivers of employee engagement as the result of the appropriate alignment of human resource practices are job characteristics, role clarity and fit, coworker and management relations, leadership, and perceptions of fairness. For this study will focus on the discussion in Leadership. Engagement and performance. The study was conducted with qualitative methods, because the study is a member of E is comprised of five members. Expected results-oriented research on the process, which leads to the performance of the data or the perspective of using inductive logic.

The addition of the new section is loaded with life-engagement in an organization will lead to a conflict of interests because of mental engagement is not in standard operational procedure (SOP) so that the top manager can skip down to the section below it to maintain harmonious relationships between the parts while waiting for the new SOP. Engagement is born of the fledgling group will face rejection old group who tend to feel overwhelmed by, so as to keep all employees who have engagement, organizations must be able to accommodate all activities and enter new that did not exist in the SOP while preparing new SOPs governing the rights and relationships responsibility of all members of the section and its auspices.
\end{abstract}

Keyword: Leadership, Engagement, Performance

\section{The Background}

People as individuals within an organization are always trying to understand what he experienced, understanding the process is influenced by individual characteristics which is supported by the organization's effective among them, leadership is able to engage individuals within the organization as a whole leads to employee engagement, has rarely been studied in the academic literature and relatively little is known about its antecedents and consequences Achievement of organizational effectiveness in desperate need of some synergic efforts of existing resources within the organization, the quality of human resources is an indicator of the success of the organization and recognized organizations are able to create effective (Becker, 2011), Employee engagement has become a hot topic in recent years among consulting firms and in the popular business press. The purpose of this study was to test a model of the antecedents and consequences of job and organization engagements based on social exchange theory Employee engagement has become a hot topic in recent years among consulting firms and in the popular business press.

The future prospect of business today is concented to be uncertain. It means that what is said to be great or well-developed may be getting worse or become out out business with any unpredictable fenomena within a relatively short time (Saks and Rotman, 2006). All materials and some properties are not surely posted to be a guarantee for the safety of future. Moreover, what is said to be unpredictable changes in business, the environtmental changes, really force the managers to employ the best strategy to combat all threats and challenges and anticipate the uncetainties anyway.

The strategies related to human resource development is felt to be much more important to accomplish the organizational goal. One of them is how to make the employees engaged because the engaged employees may be an important key to competitive advantage (Crim, 2006). The employess are said to be engaged when they have passion, commitment, and the willingness to invest themselves and expend their discretionary effort to help the employer succeed. Then, the organizational effectiveness will come to light because of the stable workforces who perform assigned duties dependably and be willing to engage in activities that go beyond roles requirements.

There are some drivers of employee engagement considerably important for the organization (Sridevi, 2010). Human resource system is the main driver of employee engagement, like staffing, training, and development practices. Those are concented to contribute to the development of employee competencies which, in turn, enhance competitive advantage and potentially maintain the organization and employee fit. Then, the remuneration system employed and performance management practices help motivate the employees to behave in ways that benefit the organization. Moreover, the organizational and job designs contribute to create a work environment conducive to employees' development and effective work systems as well. The last is that effective management and leadership development contribute to ensure a productive, fair, and supportive working environment in which employees feel motivated to achieve both departmental and organizational goals. 
The other key drivers of employee engagement as the result of the appropriate alignment of human resource practices are job characteristics, role clarity and fit, coworker and management relations, leadership, and perceptions of fairness. Job characteristics can directly affect employee attitudes and behaviors at work. Employees react positively to five core dimensions such as skill variety, task identity, task significance, autonomy, and feedback (Kulik. et.al. 1987). Role clarity helps to releive tensions between individuals and organizational needs while role ambiguity, involving the absence of clear information about one's job responsibilities, and role conflict, involving mutually incompatible job responsibilities, are known role stressors that diminish individuals' coping mechanisms and performance. Also, individuals who have rewarding interpersonal interactions with their coworkers also should experience greater meaning in their work. To the extent that coworker interactions foster a sense of belonging, a stronger sense of social identity and meaning should emerge. Then, leaders, in the organization, also play an important role by defining and communicating the organization's vision, purpose, and goals. Management openness, defined as the degree to which management is beleived to encourage and support suggestions and change initiatives from below, has also been shown to enhance employee engagement.

\section{Employee Engagement}

Employee engagement has become a hot topic in recent years among consulting firms and in the popular business press. However, employee engagement has rarely been studied in the academic literature and relatively little is known about its antecedents and consequences (Saks and Rotman, 2006). Related to the understanding on employee engagement, there are some definitions stated by management experts such as Crim, (2006). that employee engagement as the fully involved in and enthusiastic about his or her work. This definition is alligned with engagement can be characterized by energy, involvement, and efficacy. Such engagement is said to be an active engagement as high levels of activity, initiative, and resposnsibility which can be a form of the positive, fulfilling, work related state of mind that is characyerized by vigor, dedication and absorption. Engagement a emotional and intellectual commitment to the organization (Saks and Rotman, 2006), Engaged employees are physically, cognitively, and emotionally connected with their work roles. They feel full of energy, are dedicated to reach their work-related goals, and are often fully immersed in their work (Robinson, D \& Hayday.S., 2004, Bakker, 2011). The purpose of this study was to test a model of the antecedents and consequences of job and organization engagements based on social exchange theory Employee engagement has become a hot topic in recent years among consulting firms and in the popular business press. However, employee engagement has rarely been studied in the academic literature and relatively little is known about its antecedents and consequences. The purpose of this study was to test a model of the antecedents and consequences of job and organization engagements based on social exchange theory, (Saks and Rotman, 2006). Engagement represents the energy, effort, and initiative employees bring to their jobs, The psychology of how each employee connects with customers and with the organisation, Staff commitment and a sense of belonging to the organization, Context includes the culture, trust, strategy, processes and structure that exist in the organisation. Communications is about the nature and extent of dialogue and involvement that people experience at work (Kahn, W.A.1990). Work engagement is positively related to job performance (e.g., in-role performance, that is, officially required outcomes and behaviors that directly serve the goals of the organization; creativity; organizational citizenship behavior) (Bakker, 2011)

Sridevi (2010) argued that engagement is above and beyond simple satisfaction with the employment arrangement or basic loyalty to the employer. Engagement is about passion, commitment and the willingness to invest oneself and expend one's discetionary effort to help the employer succeed. Organizational effectiveness depends on more than simply maintaining a stable workforce; employees must perform assigned duties dependably and be willing to engage in activities that go beyond role requirements.

The understanding above is alligned with the concept of employee commitment characterized with a stable employee whose great contributions to the organization totally and dependably with a strong willingness to do a real activities over the given duties. Those are expected to provide a great influence on effectiveness of the organization any way.

Moreover, Harter et.al. (2003) propose that employee engagement reflect a deeper level of involvement and enthusiasm from the employee than the terms "job satisfaction" or "organizational commitment" might apply. When it is considered that having engaged employees influences how an organization performs, it is easy to grasp that employers who maximize employee engagement are those who improve their chances for busieness success. Improvement in employee engagement produce measurable improvements in business metrics. This is why the employee engagement construct is so important to business leaders today.

To create an organization that delivers sustained high levels of performance, as Kahn (1990) stated that employees must be engaged. Specifically, employees are engaged by: leaders who inspire confidence in the future, managers who respect and recognize employees., exciting work they know how to do, organization that demonstrate a genuine responsibility to their employees and communities. It is clear that properly-fitted 
leadership practices give rise to an engaged workforce, positioned to deliver the organization's customer value proposition. Loyal customers lead to market share gains, greater profitability and long term success.

Kahn (1990) also described that employee engagement as physical, emotional and cognitive participation of employee with his/her work or in other words employees' psychologically presence with high motivation in performing their organizational jobs. Also, it can be described as vigour, participation and selfefficacy in performing work which is conflicting to burnout dimensions that are cynicism, exhaustion and inefficacy.

In a simple word, employee engagement can be said as emotional and intellectual commitment to the organization (Meesala, 2011) or the amount of discretionary effort exhibited by employees in their jobs (Ram, et.al., 2011). It is characterized by energy, involvement, and efficacy, the direct opposite of the three burnout dimentions of exhaustion, cynicism, and efficacy.

\subsection{Leadership}

Workforces' development in the organization is concented to be a main factor of development and innovation. Management employs transformational leadership style to maintain the workforce development and contribution to the organization. Transformational leadership theory states that reinforcing positive behavior of manager enables followers or workers to think harder dan meaningful. Targeting follower's interests and abilities, transformational leadership can enhance the follower's commitment towards organization (Ghafoor, et.al., 2011). Transformational leadership style exhibits the culture and human resource practices that encourage employees to participate in organizational development and management. These engage them into their tasks and decision making process that is considerably useful for the future prospect of the organization.

Effective leadership is a key factor in the life and success of an organization leadership transforms potential into reality, (IAAP, 2009) The desired leadership culture, Including the leadership practices in use, such as collaboration across boundaries, engagement of employees, accepting responsibility for outcomes, creating opportunities for others to lead, developing other leaders,, learning how to learn (Pasmore, 2013), as a leadership process is the use of non-coercieve influence for the purpose of forming a group or organization, motivates behavior toward the achievement of goals. As a property, leadership is the set of characteristics that are distributed to anyone who is perceived as a leader. Thus, the leader is a person who can influence the behavior of others without having to depend on the threat of force or other forms. Along the development of leadership knowledge, formulated several contingency leadership model based approach. There are three models of leadership in the contingency approach, namely LPC models, models of path-goal, and the Vroom-Yetton Model (Vroom, 2013).

Model LPC (Least Preferred the Co-worker) developed by Fred Fiedler approach that combines the characteristics (traits) and the behavior that is the style of leader behavior is a reflection of the personality of the leader himself. Path-goal model states that the primary function of a leader is to provide valuable and desirable benefits in the workplace as well as clarify the subordinates about the kinds of behavior that will lead to the accomplishment of goals. Vroom-Yetton model focuses only on one part of the leadership process, ie, up to how much participation in decision making given to the employee, and the model predicts the level of group participation in a variety of situations.

Builds enduring greatness through a paradoxical combination of personal humility plus professional will, Level 5 Leadership (Collins, 2001).

Shift away from a world that appreciates leaders with an ultimate self-belief of control, independence and autonomy, to leaders that appreciate external forces, and recognise the importance of connection and community. (April, et.al., 2011) want to be engaged - and if they do not feel engaged, they will oon seek another situation in which they do feel valued and respected. (Douglas,G.Long, 2012)

In relation with employee engagement, transformational leadership leads to empowerment of employees that improves employee's engagement. This is the main issue of human resource pratice with which, by following this theory, organization can encourage positive work attitude and increase the quality of work. By practicing transformational leadership style pricipally develops the feeling among employees that they mean a lot and their betterment is the purpose of the organization. This aspect improves their organizational attitude leading to the quality of work being performed and exhibited. The concept of employee involvement refers to the employee interest into the tasks and jobs assigned to him. This way when an employee is involved in his tasks he/she feels psychological ownership of his job and tasks. Psychological ownership is the feeling of employee that they have responsibility to make decisions in the interest of the organization. Psychological ownership is referred to as psychological empowerment and development. It is the sense of employees that they can create, mold and make decisions and manage their work alligning with the organizational objectives. Employees feel themselves that they can influence the organization by raising their voice, efforts and capabilities considered as a job enrichment. 
The employees feel themselves empowered and developed to make decisions in undertaking to do their tasks and feel themselves accountable for taking any steps related with their tasks. When employees are secured to make any decisions on their own responsibility with the support of the organization, the level of commitment in the organization will increase. Also, they are given opportunity to involve and, then they are expected to feels psychological ownership towards their actions and their consequences, developing the sense of belonging to the the organization. These feelings develop their interest, motivation, and responsibilityas well. This enables them to perform their tasks effectively. When employees are responsible towards their tasks they make any decision with much attention and involvement which increases the opportunity of pursuing the best outcomes and meaningful fit and practices.

When employee is satisfied he develops the sense of security. Today's working environment employees have to face certain situations. These situations are related to their work tasks and ask for quick responses. Employees do not effectively perform any challenging tasks given to them because of the lack of association with work. Employees are selected after much consideration. They are trained extensively to bring best practices in the organization. Top management lacks to develop the psychological well being of employees. Physical performance depends on the psychological state of employees. Employees having blurred identity in terms of work and weak sense of belongingness are not motivated to improve their work. The feeling of dissatisfaction holds them back from performing right.

Leadership is broadly discussed topic in literature. Its antecedents and consequences have greater impact on organizational outcomes and performance. Scholars, such as contributed in the literature of leadership and its prominent styles of transactional and transformational leadership style. Transformational leadership style focuses on the development of followers and their needs. Managers exercising transformational leadership style focus on the development of value system of employees, their motivational level and moralities with the development of their skills (Ismail et.al., 2013) transformational leadership acts as a bridge between leaders and followers to develop clear understanding of follower's interests, values and motivational level it basically helps follower's achieve their goals working in the organizational setting; it encourages follower's to be expressive and adaptive to new and improved practices and changes in the environment. Transformational leadership theory explained these characteristics of leadership style.

\section{Performance}

Performance can be understood as "the achievement of results, the outcomes to which purposeful activities are directed" (Sofo, 1999). Meaning of employee performance is more emphasis on the work of the employee achieved in a certain size and time. Some experts have different views on performance measurement. Gibson et all. (2000) stated that the employee's performance is a measure that can be used to establish a comparison result of execution of tasks, responsibilities given by the organization at a certain period and can be used to measure the relative performance or the performance of the organization.

In the past decades attention to the performance of the organization employees gain a very broad support, as something of value to be achieved, improved and developed. According to Gal (2006) performance can be divided into two: 1) In-Role-Performance, performance that is demanded by the job description, employees are required to achieve it and can be suppressed by the employer to be able to achieve maximum results and 2) Extra-Role-Performance, performance is not required by the system, is interpreted as a employee social behavior due to the interaction and interdependence between the employees in the company. The work is expected in accordance with the wishes of the organization or in accordance with established standards organizations. If the work is far from standard organization, it shows that there is a gap between the performance of individual and organizational performance. If the work is far from standard organization, it shows that there is a gap between the performance of individual and organizational performance. Business organizations always try how the gap does not widen, but increasingly narrowed so that individual performance can contribute to the achievement of high performance organizations.

\section{Leadership-Engagement and Performance}

A leadership role to ensure appropriate operational components involving managerial and supervisory responsibilities are in place so that workforce engagement is a daily preoccupation of managers and supervisors in their work with employees (Hundley and Griffith, 2012). Organizations With an Increase or Decrease in Engagement. strong correlation between employee engagement and financial performance, even in turbulent financial times. (Aon Hewitt, 2012). Many factors that impact employee engagement, there are three key drivers, Relationship with immediate supervisor, Belief in senior leadership, Pride in working for the company. Employees said that it is the personal relationship with their immediate supervisor that is the key. The attitude and actions of the immediate supervisor can enhance employee engagement or can create an atmosphere where an employee becomes disengaged. Employee engagement is powerfully linked to a range of business success factors such as: Employee performance/efficiency, Productivity, Safety, Attendance and retention, Customer 
service and satisfaction, Customer loyalty and retention, Profitability. The challenge for businesses is to create an environment where employees understand and commit to the company's direction, strategy and goals. This requires a holistic, coordinated effort to ensure that a number of key elements or building blocks are in place (Michael P.Haid and Jamie , 2009)

\section{Methods}

The study was conducted with qualitative methods, because the study is a member of $\mathrm{E}$ is comprised of five members. Expected results-oriented research on the process, which leads to the performance of the data or the perspective of using inductive logic.

\subsection{Methods and Reasons to Use}

This study was conducted in an organization with a structure that can be described as follows : A is a non-profit organization leaders, choose B to lead educational services , assisted by the Chairman Education 1 (C1), Chairman of Finance2 (C2) and Chairman 3 student affairs (C3) . For services to the community to support the acceleration of B is also supported by community service agencies (D1) and Marketing Section (D2) .

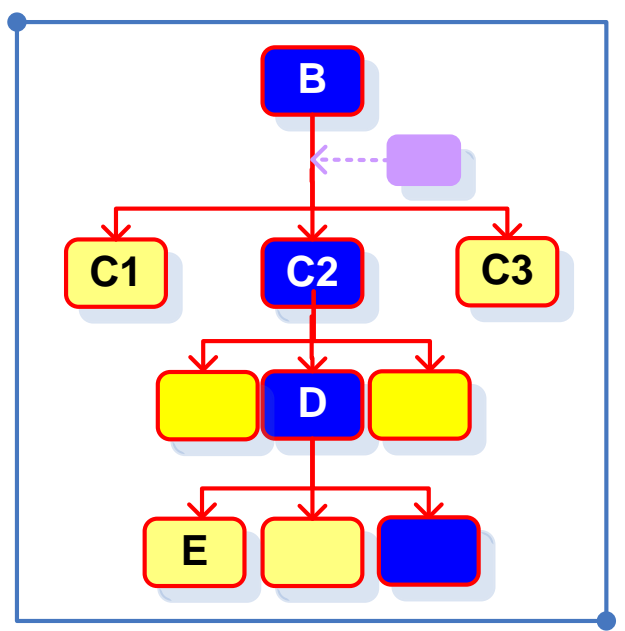

The new group engaged in aspects of the Accounting, Business and Management, especially seminars and training (E) by a structure B is placed under D1, hereinafter in this study used a qualitative design with a case study approach , then the data collected through observation , indept interview the group E. In addition, other supporters informants also involved with the aim of examining and understanding the attitudes, views, feelings and behaviors of individuals or groups of people are more sharp and complete

The study was conducted with qualitative methods, because the study is a member of $\mathrm{E}$ is comprised of five members. Expected results-oriented research on the process, which leads to the performance of the data or the perspective of using inductive logic.

\subsection{Research Design}

This study describes how a newly formed group (E) associated with the observed performance of the training and development of science in the form of seminars and other forms of coordination with agencies on it (D1). Setting this research provides a specific context so as to give a specific meaning also includes the meaning of the interaction between the individuals in the $\mathrm{E}$ in relation to the performance of $\mathrm{E}$ as well as other effects. So the research method used was qualitative research case study approach.

\subsection{The Research (Settings)}

The research is focused on the coordination room where the space $\mathrm{E}$ as a place of scientific discussion some individual members or non-members who wish to develop their knowledge $\mathrm{E}$ for collaboration and interact with all the people who have the same desire to develop knowledge and organizations where they take shelter. E activities including informants member designated as the key informants and conduct its activities. Results are expected to know the flow of thought and judgment in conducting activities related to developing a strong sense of place E shelter institutions and leadership matters boss B and D1 to employee engagement.

\subsection{Sources of Data}

Sources of data in this study were informants and documents by way of participation in dept. (Norman and Lincoln, 1997). participation in dept conducted over 6 months from the discussion about the ideals of the 
container has to participate in developing the parent organization in the field of expertise to reporting activity to $\mathrm{B}$ and D1.

Key informants in this study were 3 person shortened coordinator of E, namely EP1, EP2 treasurer and member of EP3. Other informants in this study is the president of B, assistant presiden1 (C1) and chairman of D1.

\subsubsection{Informants}

Informants in this study were ten people consisting of five E two people, President B, President $\mathrm{C} 1$ and D1 and D2., Dean LPPM, (D1).

\section{a. CABM Person (three people)}

CABM shelter under LPPM in MCE, has a mission to be the center of assessment, training and development of knowledge in the field of Business and Management Accounting, promote best practice in business and management. Both are a source of key informants of this study. CABM Person (E1, E2), and E3 treasurer.

\section{b. Management ( 3 person)}

Management is the organization in MCE, elected president of MCE (B) and Pembant President1 (C1) and the dean of LPPM (D1)

\subsubsection{Study Documents} supervisor.

Studies document in question is studying the documents relating to the reporting of E to D1 as a direct

\subsection{Ethical Considerations}

Ethical considerations in question are - matters relating to the procedures and the presence of the researcher in relation to this study, as described below.

\subsubsection{Research Instruments}

Instrument is the researcher's own research, the researcher is lecture serves as chairman of Camb. In this study used a critical ethnographic approach to research because by using this approach facilitates researchers in reviewing and following the research process in a holistic, natural and a part of history that is observed. (Sukoharsono, 1996).

To avoid biased results, researchers continue to use the rules of description and reflection in collecting the necessary data in accordance with the rules in the use of qualitative methods, both in terms of observation and in-depth interviews with informants. It can be helpful and useful for researchers, because reflection can be done directly to the management of introspection in relation to the problems studied Dawson (2002).

In addition to using the rules of qualitative methods mentioned above, to obtain valid results researchers also use triangulation techniques, which involve informants that would be helpful in verifying the data that researchers can. This is done continuously to obtain data or answers saturated. The informant helped investigators looked at the conditions that occur outside the observation of researchers. In addition to the triangulation informant interviews, also conducted on data triangulation documents such as field activities are matched to documents that have been established and continued with the interview back to verify why and what is the decision to do so.

To maintain the smoothness of the study, researchers also ethical clearance from all concerned.

\subsection{Data Collection Techniques}

In qualitative research, there are three techniques of data collection in this study, namely; Observation, interviews and document collection that will be described in more detail as follows.

\subsubsection{Observation}

Observations were conducted participant observation to active participation as a research object. Field notes were made on the principle of making field notes using descriptive and reflective notes according to (Bogdan and Bicklen in Sugiyono, 2010). Researchers conducted participant observation for six months by way of discussion involved, and put forward the idea verbally consent, so that researchers can directly ideals, processes sanpai activity reporting orally to the writing to the B and D1 


\subsubsection{Unstructured Interviews}

Unstructured interviews in addition to relying on memory which is also responsible for using the Sony ICD - UX512F as recorder for later transcribed. This recording is done openly shown to the respondents, some are hidden . this is because there is some event or events relating to any suspected problems when researchers conducted openly recording will seem awkward. The incident occurred suddenly and a moment to answer the problem

Some informants deliberately not explained openly therefore, researchers believe it may interfere with the accuracy of such information. All informants were selected to provide the expected information

In conducting the interviews and observations, researchers often get an unexpected atmosphere as speech can be considered " too familiar" so researchers have to put yourself and come late in the atmosphere . Such efforts can not be separated from the purpose of obtaining data that are considered real, not artificial and can answer any of the questions the research is expected .

The interview took place repeatedly if the data obtained is considered not enough. In addition to interviews and observations, the document is also needed to support the data observations and interniew.

\subsubsection{Document}

The document in question is a document about the recording of activity in group E These documents include; list of attendees, the evidence reliable financial and financial reports to D1.

\subsection{Processing Techniques and Data Analysis}

Analysis of the data using the Content analisys. Data analysis performed in this study is the concept of data analysis developed by Miles and Huberman (1994) in Norman KD (1997) which is an ongoing activity of a data collection, data reduction, the data display, and verification conclution, conclution drawing.

\subsubsection{Data Collection}

Data were collected from in-depth interviews and observation and then the results are recorded and copied in the form of a transcript. Researchers have an interim analysis of the results of preliminary observations or observation, then do the recording field and copied again by classifying according to the characteristics of interviews and observations based on the relevance of the objectives to be achieved from this study

\subsubsection{Data Reduction}

Researchers focus on the things that are important to look for a theme grouping, making it easier for researchers in terms of data collection further. In addition to classifying the data, the analysis was also carried out so as to give a clearer picture and focused on the goals of the research. Researchers classify based on interviews that according to, support organizations such as policies are clear, communication, working conditions, transparency and fair treatment and safety at work. Then the researchers conducted a reduction back to the things that are considered necessary grouped based picture such conditions occur, pressure, intervention, find a safe, scared seniors or superiors and others. It is easier for researchers to make a final conclusion on the condition that actually happened.

\subsubsection{Presentation of Data}

The data that have been reduced be presented in narrative form, the relationship between the categories with the hope easy to understand what the problem completely and can direct further activities.

\subsubsection{Conclusion and Verification}

Preliminary conclusions based on observations and interviews preliminary temporary. When in the process of further study there found that the data changed or fixed it can be verified again.

\section{Results and Disccution}

Facts on the ground indicate that there has been a difference in the perception of an activity between D1 and E abaut meaning and implementation activities undertaken E. Governing E sometimes report directly to $\mathrm{B}$ as a D1 supervisor, because in urgent $\mathrm{E}$ must report to D1 but he was not in place.

Occur due to differences in perception E1 feel the work has been based guidelines outline already given D1 as a direct supervisor, but the supervisor considers it is not coordinated. The above differences in this perception with style helm leadershipnya able to maintain engagement of all parties associated with the activity of $\mathrm{E}$.

To find out how different perceptions that exist, need to know in advance the expectations of each each section. The farther the difference between expectations and reality will be higher the conflict that will 
result (Winardi, 2004). Description of their expectations are D1 wants to conduct meetings, attended by all members of E together with D1 D1 in the workspace. Turns expectations regarding coordination D1 and E are not the same.

Davis (2002) says that a person's expectations in his work is influenced by the previous experience. It will establish the value of experience and the belief that someone would later influence his attitude in interacting with others. This report looks at the results of D1 meeting saying "we need redevinisi about coordination" (Z0000005.mp3)

Finally, D1 felt disregarded because members did not want E coordination meetings in the space D1. D1 Experience in the past has established value and believe in the present that form an expectation about the role of D1 in an organization. Cumming. (1999) says that the difference between one's desires and expectations with others will lead to interpersonal conflict. Interpersonal conflict is a very important dynamic in organizational behavior. Because such conflicts will involve several members of the organization that will affect the achievement of the organizational goals.

Meanwhile, according to $\mathrm{E}$ are important members of all planned activities have been reported and have got a blu print, let alone assume all steps can be answered. Step E in accordance with the principles contained in the Eisner interviews with Eisner and Luthans (Luthans, 2005), ...."i mean that I just don't forget things. I don't keep my notes, but once something is in my head, I can't get rid or it until I think it has been stuck into somebody else's head". The lack of recognition of the boss will raise doubts and concern for his subordinates, is evident from the expression of E members said that: ... "I have not given a report which will include the document because when asked to put hand over his desk, but he did not carry worry cocoa original file is missing .." (Z0000004.mp3)

Gothe \& Koster, (2007) said that the sense of security and well treated on the job is one of the important factors forming satisfaction. Luthans (2005) said, conflict divides into five kinds, namely; Intrapersonal conflict, interpersonal conflict, conflict between individuals and groups, conflict between groups within the same organization and between the organization's Conflict.

Moore (1986), describes five categories of conflict: the data, relationships, values, structures and interests. substantive conflict of interest, arising from the situation relating to the allocation of resources or space used. Specific conflict situations often involve elements of more than one of the five categories above.

Based on the theory of the distribution of types of conflict, it can be concluded that the conflict in the organization led B is a conflict between groups within the organization. The conflict between groups within the organization, is the conflict between a person in a group with other people because of a conflict of interest or desire or conflict groups and organizations because of differences in perception caused unclear Standard Operational Procedure (SOP). This kind of conflict will involve several roles of some members of the organization will affect the achievement of the organizational goals.

Conflict between D1 and E and B. Each member - each personal gain of any other personal pressures, due to conflicts of interest, especially the conflict between the interests of D1 and E. The following quote about conflict between groups within the organization that occurs between them.

Chairman D1 conflict with members of the E looks of sentences that came out at the time of all members of the E and B -and all the officials under him (Z0000009.mp3) "... why E is not coordinating with us? .." ........ Chairman E explain .... "Previously we had reported to D1, and the mother made a draft of the letter .... "The difference in perception occurs and thus fair to both the leadership style is true, according to (Novlan, 2014) is tired leadership leadership and care of all the things that have been delegated to the team competent enough waiting for the final results report; delegation will ease the task of the boss and will encourage subordinates job satisfaction and engagement.

When referring to the theory of the cycle of conflict by Moore, the conflict in the organization led by B is a conflict of interests. The conflict, relating to a person's needs and interests of a person. Substantive interests are problems procedures, which became the procedural interests is due to the absence of SOPs.

Seeing conditions occur, to protect and support the engagement member E, B says: "Activity E forward, we thank you in a very short time, activity $E$ is already a success and for the future it should be discussed with both .... (Z0000012.mp3) " Followed by C1 ... Birth of E is like the birth of miracle baby because it has been able to organize national and international seminars .... (Z0000014.mp3) ", respectively each officer even helped give special recognition to the team of E. In the event that the meeting was attended by all members of management, $\mathrm{C} 1$ expressed his opinion:" I am very proud to all members of the group $\mathrm{E}$.... (Z0000017.mp3), if I may assume, group $\mathrm{E}$ is like a newborn baby miraculously been able to run ......... (Z0000015.mp3) "Opinions are very reasonable so as to implement the international level seminars number of attendees and the cost can be reduced.

Model C1 expression in line with the path-goal, Level 5 Leadership (Collins, 2001), which states that the primary function of a leader is to provide valuable and desirable benefits in the workplace as well as clarify the subordinates about the various behaviors that will lead to completion purpose. Vroom-Yetton Model Further 
focusing attention on the process of leadership, that is up to how much participation in decision making given to employees, and this model can increase the level of participation of the group in a variety of situations.

$\mathrm{C} 1$ expression is not making a appreciates leaders with the self-belief of control, independence and autonomy, able to recognise the importance of connection and community (April, et.al., 2011), want to be engaged - and if they do not feel engaged, they will seek another oon situation in the which they do feel valued and respected (Douglas, G.Long, 2012). Recognition as a leader to give kesempatann ledge on its members to achieve peak performance by providing support and get rid of the factors inhibiting performance (Stave, 2011).

However, according to D1 is considered no communication errors between D1 and E. The miscommunication occurred D1 inferred from the words ... "I do not think so sir ..... Ben's sense of coordination, we have to redefine what the meaning of coordination that ....." said they appear after E considered coordination, in terms of $\mathrm{E}$ was already coordinating with D1. the costs, and other invitation letter to whom will decide its own consultation. Standard operating procedure is not executed, resulting in decisions that are not in line with expectations D1.

More broadly, procedural interests conflict is caused by the lack of firmness and authority management in leading and managing organizations in the history of the founding B. E may help explain the situation. E stands at the initiative of two people who have a scientific discussion forum and led organizations committed to making B as a scientific discussions and seminars, as well as participated in growing organization. Support the leadership of the group E by Stave (2011) is a redesign job dilibtkan to change the way employees work, introducing variations in the workings, delegate authority, members the opportunity to engage employees in the organization, so that employees feel valued and gained recognition both of the groups and organizations exist. Then in a short period of member-led organization B being attracted to the ideals of the group E, there are 5 people to join and to maintain the dishonesty, the collegial model of leadership is the leadership organization shaped $\mathrm{E}$ could not make a decision if the member does not agree. In this study, the informant said: ".... sir, I salute the founding of $\mathrm{E}$....... I helped from behind it, because we are in the seminar series of activities carried out in the not terncanakan but we carried on to fill the void of activities necessary institutions, I got a reproof of the D1 ....... so I learned my lesson. "collegial leader Furthermore E evaluated the relationship is not harmonious with the D1 and asked its members:" (Z000011.mp3) how the father and mother if the organization E is forwarded or stopped? ..... it aklamsi said: "forwarded, the activities we have started to look important ideals that we still participate in developing our campus"(Z0000008.mp3).

The results of these interviews, suggests that the activities of the group E is highly expected by all parties. Although procedurally must be stated in the SOP.

\section{Conclusion}

The addition of the new section is loaded with life-engagement in an organization will lead to a conflict of interests because of mental engagement is not in standard operational procedure (SOP) so that the top manager can skip down to the section below it to maintain harmonious relationships between the parts while waiting for the new SOP.

Engagement is born of the fledgling group will face rejection old group who tend to feel overwhelmed by, so as to keep all employees who have engagement, organizations must be able to accommodate all activities and enter new that did not exist in the SOP while preparing new SOPs governing the rights and relationships responsibility of all members of the section and its auspices.

appreciates leaders with the self-belief of control, independence and autonomy, able to recognise the importance of connection and community, want to be engaged - and if they do not feel engaged, they will seek another oon situation in the which they do feel valued and respected.

In the development of the organization to encourage the performance of the organization in recent decades continue to run very fast of attention on organizational commitment, increased in the locus of control, and lately has been focused on engagement, engagement indicators-indicators that need to be incorporated into the key performance indicators, although not in the SOP, as indicators-indicators are able to expend resources to encourage new ideas that have not been accommodated in IBC and SOP, but it helps improve the image and performance of organizations exist.

\section{Library}

[1]. April, Kurt, at.al, 2011, Leader Career Success \& Locus of Control Expectancy, Academy of Taiwan Business Management Review

[2]. Aon, Hewitt, 2012, Trends in Global Employee Engagement, http://www.aon.com/attach-ments/thoughtleadership/Trends_Global_Employee_Engagement_Final.pdf

[3]. Bakker, Arnold B, 2011, An Evidence-Based Model of Work Engagement, http://home.ubalt.edu/NTYGMITC/641/bakker\%20evidence\%20based\%20mode1\%20engage-ment.pdf

[4]. Collins, Jim, 2001, harvard business review, january 2001, http://gsblive.uct.ac.za/instructor/usermedia/1650/Collins\%202001 2.pdf

[5]. Cummings, P.W. 1999. Open Management: Guides to Successful Practice, Amacom. New York. 
[6]. Crim, Dan, 2006, What Engages Employees The Most or the ten C's of Employee Engagemen, Ivey Business Journal, http://iveybusinessjour-nal.com/topics/the-workplace/what-engages-employees-the-most-or-the-ten-cs-of-employee-engagement

[7]. $\quad$ Davis, K \& Newstorm, JW. 2002. Human Behavior at Work Organizational, Mc Graw Hill Inc. New York.

[8]. Dawson, C .2002. Metode Penelitian Praktis, How to Books Ltd, Penerbit Pustaka Pelajar. Yogyakarta.

[9]. Douglas,G.Long, 2012, Third Generation Leadership and the Locus of Control, http://www.gowerpublishing.com/isbn/9781409444534

[10]. Gal, Peter, 2006, Motivation and Performance, Comenius University, Slovac Republic.

[11]. Ghafoor, Azka, at.all., 2011, Transformational leadership, employee engagement and performance: Mediating effect of psychological ownership, African Journal of Business Management Vol. 5(17),

[12]. Gibson, I \& Donneley, 2000, Organization, Irwin/McGraw-Hill, Gramedia, Jakarta.

[13]. Gothe, H \& Koster, AD .2007. 'Job satisfaction among doctors, a review of international literature', Journal of Health Management 7 (5).

[14]. Hundley, Stephen P and Daniel B. Griffith, 2012, At the Intersection of Leadership and Engagement Stands HR, http://www.cupahr.org/hew/files/HEWorkplace-Vol4No1-Intersection.pdf

[15]. Harter, James K, Frank L. Schmidt, Emily A. Killham, 2003, Employee Engagement, Satisfaction, and Business-Unit-Level Outcomes: A Meta-Analysis, The Gallup Organization, http://www.nova.edu/ie/ice/forms/meta analysis july 2003.pdf

[16]. IAAP, 2009, Theories and Styles Leadership, Administrative Professionals Week Event Event April 28, 2009, http://www.etsu.edu/ahsc/documents/Leadership_Theories.pdf

[17]. Ismail, Azman, at.all., 2013, Social support in job performance as an attecedent of work intrusion on family conflict, Management, Vol. 18, 2, https://www.efst.hr/ma-nagement/Vol18No2-2013/3-Ismail\%20Mohd\%20Nor\%20et\%20al.pdf

[18]. Kahn, W.A., 1990, Psychological Conditions of Personal Engagement and Disengagement at Work. Academy of Management Journal, vol. 33, 4

[19]. Kulik, C.T, at.all., 1987, Work Design as an Approach to Person-Environment Fit, Journal of Vocational Behavior, vol.3, 1.

[20]. Luthans,Fred, 2002, Organizational Behavior, Ninth Edition, McGraw-Hill Irwin, Boston

[21]. Michael Haid and Jamie , 2009, Employee engagement: Maximizing Oganizational Performance, Right Management Inc. Philadelphia, http://www.right.com/thought-leadership/research/employee-engagement---maximizing-organizational-performance.pdf

[22]. Meesala, Appalayya, 2011, Identification of Engaged Employee Groups: Who all are the Full -Throttles, the Wet-Behind-the-Ears, and the Past-the-Primes in India?,

[23]. Moore, CW. 1996. The Mediation Process: Practical Strategies for Resolving Conflic, Jossey-Bass. San Francisco.

[24]. Norman, KD \& Lincoln. YS.,1997, Hand Book of Qualitative Research, Pustaka Pe-lajar. Yogyakarta.

[25]. Novlan, Yosi, 2014, Strong Leadhersip, Prima Qualita, Surabaya

[26]. Pasmore, William, 2013, Developing a Leadership Strategy, Center of Creative Leadership http://www.ccl.org/leadership/pdf/research/LeadershipStrategy.pdf

[27]. Ram, Padmakumar, Gantasala V. Prabhakar, 2011, The role of employee engagement in work-related outcomes, Interdisciplinary Journal of Research in Business Vol. 1, Issue. 3

[28]. Robinson, D., Perryman. S \& Hayday.S. ,2004, The Drivers of Employee Engage-ment. Institute for employment studies, Brighton, UK.

[29]. Saks, Alan M and Joseph L. Rotman, 2006, Antecedents and consequences of employee engagement, Journal of Managerial Psicology, Vol. 21 No. 7

[30]. Sridevi, M. Sandhya, 2010, Employee Engagement: The Key to Improving Performance, International Journal of Business and Management Vol. 5, No. 12

[31]. Stave, P, (2011), Keep Your Best People, PT.Gramedia Pustaka, Jakarta

[32]. Sugiyono. 2010. Memahami Penelitian Kualitatif, Alfabeta. Bandung.

[33]. Sukoharsono, EG. 1996. 'Refleksi ethnography kritis pilihan lain teknik riset akutansi', Jurnal Akutansi dan Bisnis 4 (1).

[34]. Sofo, Fransco, 1999, Human Resources Management, Perspectives, Roles, and Practice Choise, Business \& Profesional Publising, Australia.

[35]. Vroom, H.Victor, 2013, Educating managers for decision making and leadership, Management Decision, $41 / 10$ https://www.hrmeter.com/files/VroomArtikel fuerWeb.pdf

[36]. Winardi. 2004. Manajemen Konflik (Konflik Perubahan dan Pengembangan), CV Mandar Maju. Bandung. 